\title{
0 pierwszeństwie interpretacji przed ontologią. Przyczynek do krytyki realizmu w filozofii nauk społecznych
}

\section{On the Priority of Interpretation over Ontology. A Contribution to the}

\section{Critique of Realism in the Philosophy of Social Sciences}

\begin{abstract}
The article is devoted to the critical discussion of realism and interpretative approach in the philosophy of social sciences. The thesis of the paper states that interpretation is prior to realist ontology in three ways. First, to understand science (including natural sciences) we need to interpret culturally specific practices of various communities of inquiry rather than pursue general metaphysical questions about the nature of reality. Second, from an interpretative perspective general image of social and political reality is seen as an outcome of interpretative struggle between various ideological traditions. Finally, according to interpretative approach research practice in social and political disciplines is not predetermined by prior ontological assumptions. Due to this fundamental openness of social inquiry it is better to interpret it in terms of Gadamerian metaphor of hermeneutic circle or pragmatic metaphor of problem-solving.
\end{abstract}

Keywords: pragmatism, hermeneutics, realism, anti-realism, constructivism, instrumentalism

Interpretacjonizm i realizm są stanowiskami w zakresie filozofii nauk społecznych, które zrodziły się ze sprzeciwu wobec pozytywizmu. Chociaż oba te nurty filozoficzne odrzucają standard metodologiczny forsowany przez pozytywistów, to jednak różnią się w kwestii tego, czym należy zastąpić pozytywistyczne samorozumienie nauk społecznych. Interpretacjoniści lansują model nauk społecznych wzorowany na humanistyce, który przyznaje centralne znaczenie takim kategoriom jak znaczenie i interpretacja. Realiści z kolei dowartościowują ontologiczną warstwę teorii naukowych, która była przez pozytywizm niedostrzegana lub piętnowana jako pozbawiony znaczenia relikt metafizyki. Trzeba powiedzieć, że te dwie krytyki w dużym stopniu uzupełniają się. Bardziej wyra- 
finowani realiści starają się uwzględnić główne zdobycze hermeneutyki, przyznając takim kategoriom, jak metafora, interpretacja czy społeczna konstrukcja znaczenia, istotne miejsce $\mathrm{w}$ realistycznej filozofii nauki. Interpretacjonista natomiast mógłby zgodzić się z tezą realisty, że teorie rozwijane $\mathrm{w}$ naukach społecznych zawierają jawne lub ukryte założenia o charakterze ontologicznym, a nawet przyznać, iż teorie te byłyby w zasadzie niemożliwe do pomyślenia bez ogólnych twierdzeń na temat natury rzeczywistości społecznej. Akceptacja tej konstatacji nie oznacza jednak przyjęcia stanowiska realistycznego. Każdy pogląd, który zasługiwałby na miano realistycznego w sensie filozoficznym, musi bowiem dodatkowo utrzymywać, że przynajmniej niektóre $\mathrm{z}$ owych ogólnych właściwości rzeczywistości społecznej są wolne od czynników „subiektywnych”, takich jak znaczenie i interpretacja, a nawet więcej - że nasze wysiłki poznawcze muszą ostatecznie być oceniane przez pryzmat zgodności teorii z rzeczywistością istniejącą niezależnie od różnych sposobów jej pojęciowego ujmowania. Realista chce bowiem poznać rzeczywistość obiektywną - taką, jaka ona jest sama w sobie, bez względu na przyjmowane przez nas interpretacje. Na to, rzecz jasna, interpretacjonista zgodzić się nie może.

$\mathrm{W}$ artykule przedstawię krytykę stanowiska realistycznego z punktu widzenia interpretacjonizmu. Stąd tytułowa teza o pierwszeństwie interpretacji przed ontologią. Pierwszeństwo interpretacji nad realistycznie pojmowaną ontologią będę rozpatrywać na trzech płaszczyznach: filozofii nauk przyrodniczych, filozofii polityki (lub teorii społecznej, gdyż idzie tu o wszelkie wypowiedzi na temat charakteru rzeczywistości społecznej) oraz praktyki badawczej realizowanej w obrębie nauk społecznych. Po pierwsze, mam zasadnicze zastrzeżenia wobec realistycznej interpretacji nauk przyrodniczych. Jako pragmatysta sądzę mianowicie, że o tym, czym jest nauka, dowiadujemy się, analizując konkretne przypadki podejmowanych przez ludzi badań, nie zaś stawiając filozoficzne pytania o naturę poznania czy charakter rzeczywistości. Interpretacja, rozumiana tutaj jako próba uchwycenia sensu kulturowo zakorzenionych praktyk naukowych, ma więc pierwszeństwo przed ontologią, pojmowaną jako dążenie do stworzenia na bazie ustaleń nauki ogólnej teorii rzeczywistości. Po drugie, utrzymuję, że nasz ogląd rzeczywistości społecznej - zatem główny przedmiot zainteresowania filozofii polityki, a zarazem dziedzina, którą realista chciałby określić mianem ontologii - sam jest produktem społecznych procesów nadawania i kontestowania znaczenia. Za Stanleyem Fishem możemy powiedzieć, iż to, jak postrzegamy świat, zależy od języka, którym się posługujemy, natomiast to, jakim językiem się posługujemy, zależy z kolei od wspólnoty interpretacyjnej, do której - świadomie lub nie - należymy (Fish, 2002, s. 99-119). Innymi słowy, obiektywny ogląd rzeczywistości, do którego dąży realista - a więc taki ogląd świata, który sytuowałby się ponad konfliktem interpretacji - jest niemożliwy do uzyskania. Po trzecie wreszcie, twier- 
dzę, że w praktyce badawczej nauk społecznych nacisk położony na ontologię prowadzi często do nadmiernie hierarchicznego obrazu poznania naukowego. Dla interpretacjonisty, który jest również pragmatystą, proces badawczy ma charakter otwarty i nie jest zdeterminowany przyjętymi uprzednio założeniami ontologicznymi, natomiast poszczególne teorie i metody traktowane są jako narzędzia służące różnym celom badania, nie zaś jako mniej lub bardziej adekwatne próby odwzorowania obiektywnej rzeczywistości społecznej.

\section{Uwagi wprowadzające: metoda, ontologia i interpretacja}

Zamierzam zestawić ze sobą trzy filozoficzne interpretacje nauk społecznych, które można określić mianem pozytywistycznej, interpretacjonistycznej albo hermeneutycznej oraz realistycznej. Stanowiska te występują w rozlicznych odmianach, wszystkie one też podlegały rozmaitym przemianom w czasie. Dlatego mam zamiar przyjąć pewne - mam nadzieję, że nie nazbyt arbitralne - ustalenia definicyjne dotyczące tego, co będę rozumieć przez pozytywizm, interpretacjonizm i realizm. Konstruowane przeze mnie definicje mają wydobyć motyw, który uważam za najbardziej charakterystyczny dla pozytywistycznego, interpretacjonistycznego i realistycznego rozumienia nauki. Jednocześnie mają być one na tyle ogólne, aby uwzględniały większość - jeżeli nie wszystkie - stanowisk mieszczących się w obrębie wymienionych nurtów.

Zacznijmy od pozytywizmu. Wyróżnikiem orientacji pozytywistycznej w naukach społecznych jest nacisk położony na szeroko pojętą metodę naukową (Krauz-Mozer, 2005; Bernstein, 2015, s. 21-70; Benton, Craib, 2003, s. 9-62). Mianem pozytywizmu określam więc stanowisko, które zakłada, że: (1) poznanie naukowe ma charakter metodyczny, lub też, innymi słowy, że posługiwanie się odpowiednią metodą odróżnia naukę od tego, co nauką nie jest; (2) istnieje - zasadniczo - jeden standard metodologiczny, wspólny dla nauk przyrodniczych i społecznych; (3) postęp nauk społecznych daje się mierzyć w zależności od tego, czy zbliżamy się do właściwego standardu metodologicznego. Pod pojęciem metody rozumiem nie tylko sprecyzowany zestaw następujących po sobie kroków, ale również bardziej ogólne przekonanie, że istnieje jakiś szczególny, właściwy nauce sposób sprawdzania hipotez. W tym sensie zarówno empiryzm logiczny, jak i falsyfikacjonizm Poppera byłyby teoriami na temat metody. Rzecz jasna, rzecznicy popperyzmu protestowaliby zapewne przeciwko wrzuceniu ich teorii do jednego worka ze zwalczanym przez nich weryfikacjonizmem. Mimo to sądzę, że taki zabieg jest prawomocny, gdyż to, co łączy oba te podejścia - akceptacja hipotetyczno-dedukcyjnego modelu teorii naukowej, nacisk na testowanie hipotez, normatywna koncepcja metodologii jako dyscypliny określającej 
obowiązujące normy postępowania naukowego - wydaje się z dzisiejszej perspektywy ważniejsze niż dzielące je różnice. Ukształtowana pod auspicjami pozytywizmu wizja nauki określała - i w znacznym stopniu nadal określa - samorozumienie badaczy sytuujących się w głównym nurcie współczesnych badań społecznych. W naukach o polityce nurt pozytywistyczny reprezentowała rewolucja behawioralna, a także podejścia czerpiące $\mathrm{z}$ instrumentarium ekonomii neoklasycznej, takie jak teoria racjonalnego wyboru.

Przez realizm rozumiem stanowisko, które głosi, że: (1) nauka jest teorią na temat rzeczywistości (ontologią); (2) owa rzeczywistość jest obiektywna, to znaczy istnieje niezależnie od podmiotów poznających i przyjętego przez nie języka opisu; (3) zadaniem nauki, w tym nauk społecznych, jest adekwatne ujęcie rzeczywistości, to znaczy dostarczenie wiedzy na temat tego, jaki świat jest obiektywnie - niezależnie od celów aktorów społecznych czy pojęć, którymi się oni posługują. Zauważmy, że z punktu widzenia nauk społecznych problematyczny wydaje się drugi punkt zaproponowanej definicji. Otóż nauki społeczne zajmują się właśnie tą częściową rzeczywistości, która byłaby niemożliwa bez aktywności człowieka. Niemniej jednak właśnie ten punkt jest dla realizmu kluczowy. Bez założenia o obiektywnym charakterze rzeczywistości mielibyśmy być może jakąś ontologię, ale nie byłaby ona realistyczna w sensie, jaki jest zazwyczaj zakładany w filozofii. Problem ten realiści rozwiązują na różne sposoby. Niekiedy postuluje się istnienie określonych mechanizmów lub zdolności (capacities), które są traktowane jako nieodzowne do wyjaśnienia relacji przyczynowych obserwowanych w świecie naturalnym lub społecznym (Elster, 1989, s. 3-10; Cartwright, 1989; Cartwright, 2009). Inna - i chyba częściej stosowana - realistyczna strategia przyjmuje określoną stratyfikację rzeczywistości społecznej, wskazując zarazem na istnienie takich jej wymiarów, które są całkowicie niezależne od przyjętych interpretacji (Benton, Craib, 2003, s. 144-149). Głębsze warstwy rzeczywistości społecznej są utajone, a ich ujawnienie jest możliwe jedynie przy zastosowaniu właściwych narządzi teoretycznych. Realizm przyjmuje zatem klasyczne, dualistyczne rozróżnienia na podmiot i przedmiot, pozór i rzeczywistość, prawdę i złudzenie. W filozofii nauk społecznych realizm jest reprezentowany przez brytyjskich krytycznych realistów kontynuujących myśl Roya Bhaskara, a także przez takich autorów jak Martin Hollis czy Uskali Mäki (Benton, Craib, 2003, s. 139-162; Outhwaite, 1987; Hollis, 2003; Mäki, 2001b). W naukach politycznych podejście to reprezentują między innymi David Marsh i Paul Furlong, autorzy rozdziału wprowadzającego do wpływowego podręcznika Teorie i metody w naukach politycznych (Marsh, Furlong, 2016).

Wreszcie na koniec chciałbym przedstawić stanowisko interpretacjonistyczne, a mówiąc ściślej, pewną wersję tego stanowiska, która łączy hermeneutyczną wrażliwość z inspiracjami czerpanymi z filozofii amerykańskiego pragma- 
tyzmu ${ }^{1}$. Pragmatyczny interpretacjonizm proponuję scharakteryzować poprzez następujące trzy tezy: (1) nie istnieje żadna rodzajowa różnica między tradycyjną filozofią polityczną a nowoczesnymi naukami społecznymi, lub też - innymi słowy - projekt stworzenia nauk społecznych wzorowanych na przyrodoznawstwie nie powiódł się; (2) rzeczywistość społeczna jest konstruowana językowo i może być rozumiana w sposób analogiczny do tego, w jaki staramy się zrozumieć tekst $-\mathrm{z}$ tego względu interpretacja jest najbardziej ogólnym ujęciem procedury stosowanej w naukach społecznych, a być może nawet w nauce tout court; (3) poszczególne teorie, metody i techniki badawcze należy traktować w sposób instrumentalistyczny jako narzędzia służące rozmaitym celom badania. Interpretacjonizm kształtował się w opozycji do nauk społecznych modelowanych na przyrodoznawstwie lub też - mówiąc ściślej - na pozytywistycznym rozumieniu tego, czym są nauki przyrodnicze (Bernstein, 2015, s. 75-140). W związku z tym może on być postrzegany jako próba dowartościowania klasycznej humanistyki i uczynienia z niej modelu dla nauk społecznych. Choć rozmaite podejścia interpretacjonistyczne występowały w naukach społecznych niemal od początku ich istnienia - można tu wymienić między innymi Weberowską socjologię rozumiejącą, socjologię humanistyczną Floriana Znanieckiego, interakcjonizm symboliczny czy fenomenologię Alfreda Schütza - to współczesne oblicze tego nurtu zostało ukształtowane przez zwrot językowy w filozofii i myśli współczesnej. Dla powstania stanowiska interpretacjonistycznego w naukach politycznych szczególne znaczenie miała krytyka rewolucji behawioralnej przedstawiona przez Charlesa Taylora i Alasdaira MacIntyre’a (Blakeley, 2016). Obecnie interpretacjonizm jest żywą tradycją badawczą, obejmującą dociekania prowadzone w sferze badań nad politykami publicznymi, ekonomią polityczną czy integracją europejską (Bevir, Rhodes, 2016; Grzymski, 2016).

Współczesne zainteresowanie takimi orientacjami, jak realizm i interpretacjonizm, wynika $z$ faktu, że pozytywizm nie był w stanie wywiązać się ze składanych przez siebie obietnic. Pomimo znacznych funduszy, zaangażowania najwybitniejszych umysłów, intensywnego rozwijania zaawansowanych metodologii ilościowych i trwających przez ponad pół wieku wysiłków nauki społeczne nie zdołały przybliżyć się do standardów lansowanych przez rzeczników pozytywizmu. Próby dookreślenia wymogów, jakim zdaniem pozytywistów powinna sprostać teoria naukowa, prowadziły do wniosku, że żadna $\mathrm{z}$ teorii sformułowanych w naukach społecznych tych kryteriów nie spełnia (Krauz-Mozer, 2005, s. 62; Bernstein, 2015, s. 42-51). Sceptycyzm wzmacniała dodatkowo po-

Naszkicowane tutaj stanowisko pragmatycznego interpretacjonizmu mam nadzieję przedstawić szerzej w książce poświęconej politologii interpretującej, nad którą pracuję razem ze Stanisławem Filipowiczem i Janem Grzymskim. 
wszechnie akceptowana konstatacja o braku sukcesu predykcyjnego w naukach społecznych, który dałoby się porównać $\mathrm{z}$ osiągnięciami nauk przyrodniczych w tym zakresie. Pod wpływem tych i podobnych obserwacji lansowana przez pozytywistów metodologia nauk społecznych zaczęła jawić się jako rytuał imitacyjny, polegający na naśladowaniu nie tyle nawet samych nauk przyrodniczych, ile raczej pewnego filozoficznego wyobrażenia na ich temat. Z dzisiejszej perspektywy łatwo dostrzec, że pozytywistyczna filozofia nauk społecznych miała $\mathrm{w}$ istocie religijny charakter. Wyczekiwanie na Newtona czy Einsteina nauk społecznych przypomina jako żywo wiarę w nadejście Mesjasza, natomiast rozmaite przejściowe sukcesy takich czy innych podejść badawczych (najczęściej jakiejś wersji funkcjonalizmu lub behawioryzmu) traktowane są jako znaki mówiące, że moment ten wkrótce nastąpi. Mesjanistyczny zapał oznacza, że słuszność pozytywistycznych wskazań metodologicznych może być potwierdzona jedynie w przyszłości, kiedy to nauki społeczne osiągną zdefiniowany przez pozytywizm standard naukowej dojrzałości. Za takie nastawienie pozytywizm musi jednak zapłacić określoną cenę w postaci przyznania, że aktualna praktyka badawcza w naukach społecznych nie daje się adekwatnie wyjaśnić w ramach kanonów pozytywistycznej metodologii.

Pod zarysowaną wyżej krytyką pozytywizmu podpisałaby się, jak sądzę, większość zwolenników realizmu i interpretacjonizmu. Niemniej jednak istnieją między tymi nurtami istotne rozbieżności, które dochodzą do głosu w polemikach prowadzonych przez rzeczników owych podejść. Mam tu na myśli debatę Ernesta Laclaua z Royem Bhaskarem (Bhaskar, Laclau, 1998) oraz - na polskim gruncie - dyskusję realisty Łukasza Hardta $\mathrm{z}$ konstruktywistą Bartoszem Scheuerem w filozofii ekonomii (Hardt, 2016; Scheuer, 2016). Niniejszy tekst traktuję jako przyczynek do współczesnych debat w filozofii nauk społecznych. Moim celem jest zlokalizowanie punktów spornych między realizmem a interpretacjonizmem oraz pokrewnymi orientacjami, a także przedstawienie argumentów, które przemawiają na rzecz wyższości stanowiska interpretacjonistycznego.

\section{Realizm, instrumentalizm i konstruktywizm}

Jak przekonuje Arthur Fine, realizm w filozofii nauki ma podwójne oblicze (Fine, 1998, s. 560). W aspekcie epistemologicznym utrzymuje on, że sukces teorii naukowej w zakresie wyjaśniania i przewidywania uzasadnia na ogół wiarę w jej prawdziwość. W aspekcie metafizycznym realizm twierdzi, że istnieje rzeczywistość niezależna od umysłu oraz że może ona być przedmiotem poznania naukowego. Przy takim rozumieniu realizmu łatwo określić tożsamość jego głównych oponentów. Otóż pod względem epistemologicznym realizmowi prze- 
ciwstawia się instrumentalizm głoszący, że teorie naukowe są raczej użytecznymi narzędziami niż wiernymi reprezentacjami obiektywnej rzeczywistości. Pod względem metafizycznym zaś głównym przeciwnikiem realizmu są różne orientacje konstruktywistyczne, utrzymujące, że wiedza naukowa ma charakter konstruktu lub artefaktu wytworzonego przez określone wspólnoty badania (Zybertowicz, 1995; Bińczyk, 2013). Większość argumentów zarówno za realizmem, jak i przeciw niemu ma swoje źródło w filozofii nauk przyrodniczych. $Z$ tego powodu dyskusja o perspektywach realistycznych nauk społecznych musi być poprzedzona analizą trudności, na jakie napotkała realistyczna interpretacja przyrodoznawstwa. W pewnym uproszczeniu można powiedzieć, że realizm rozbił się o dwie rafy - tezę Duhema-Quine’a o niezdeterminowaniu teorii przez dane oraz tezę o niewspółmierności formułowaną szczególnie wyraźnie przez Thomasa Kuhna i Paula Feyerabenda. Przyjrzyjmy się zatem, jakie trudności dla realistycznej interpretacji nauki stwarzają te dwa twierdzenia.

Teza o niezdeterminowaniu teorii przez dane była przede wszystkim krytyką poglądu, że teorie naukowe mogą zostać potwierdzone lub obalone w wyniku konfrontacji z empirią (Harding, 1976). Pogląd ten występuje w wielu odmianach, które różnią się istotnie między sobą. Najogólniej rzecz biorąc, rzecznicy tezy Duhema-Quine’a utrzymują, iż teorie naukowe nigdy nie są odrzucane wyłącznie na podstawie danych empirycznych lub wyników przeprowadzonych eksperymentów. Dzieje się tak dlatego, że teoria jest tworem złożonym, składającym się $\mathrm{z}$ wielu hipotez i założeń pomocniczych. W przypadku niepomyślnego przebiegu eksperymentu to badacze muszą rozstrzygnąć, czy daną teorię należy zmodyfikować, czy całkowicie odrzucić, a także które aspekty teorii powinny ulec zmianie. W wersji silniejszej teza o niezdeterminowaniu teorii przez dane zakłada, że potencjalnie nieskończona liczba teorii może zostać uzgodniona $z$ dostępnymi danymi empirycznymi. W związku z tym względy empiryczne nie są dostateczną przesłanką do dokonania wyboru między konkurencyjnymi teoriami. Jak nietrudno zauważyć, pogląd ten jest przede wszystkim krytyką tradycyjnego empiryzmu oraz falsyfikacjonizmu Poppera, a nie filozofii realistycznej. Co więcej, realista może utrzymywać, iż teza o niezdeterminowaniu daje się uzgodnić z realistycznym poglądem, że teorie naukowe posiadają warstwę ontologiczną, która nie podlega bezpośrednim testom empirycznym (Mäki, 2001a, s. 9). Jednak przy bliższym zbadaniu okazuje się, że teza Duhema-Quine’a niesie ze sobą implikacje, które podważają jedną z kluczowych realistycznych intuicji. Tradycyjny realizm traktował bowiem następujące po sobie teorie naukowe jako kolejne kroki w procesie przybliżania się do poznania obiektywnej rzeczywistości. Jeżeli teorie nie są zdeterminowane przez dane empiryczne - tak jak sugeruje to teza Duhema-Quine'a - to z pewnością nie są też one zdeterminowane ontologicznie. Innymi słowy, dwie teorie naukowe mogą być empirycznie równoważ- 
ne, a mimo to propagować sprzeczne i niedające się ze sobą pogodzić wizje świata. Dodajmy, że ten aspekt niedookreślenia teorii przez dane ma duże znaczenie dla dyskusji prowadzonych w naukach społecznych, gdzie zwolennicy konkurencyjnych orientacji teoretycznych, takich jak liberalizm i marksizm, powołują się często na te same fakty dla uwiarygodnienia lansowanych przez siebie wizji świata (Lukes, 1978, s. 93).

Podobne trudności dla realistycznej interpretacji nauki stwarza lansowana przez Kuhna i Feyerabenda teza o niewspółmierności różnych teorii i paradygmatów naukowych (Bernstein, 1983, s. 51-108). Również ta teza występuje $\mathrm{w}$ wielu wersjach, istotnie różniących się między sobą. Na najbardziej ogólnym poziomie głosi ona, że nie istnieje ciągłość znaczeniowa w zakresie sposobu definiowania kluczowych pojęć między niewspółmiernymi teoriami naukowymi. Oznacza to, że sposób rozumienia zasadniczych dla nauki terminów podlega nieustającym zmianom w czasie, a także że pojęcia przyjmowane $\mathrm{w}$ obecnie uznanych teoriach nie mogą być traktowane jako uszczegółowienie lub rozwinięcie uprzednio stosowanej aparatury pojęciowej. Dotyczy to zarówno terminów używanych w samych teoriach naukowych, takich jak grawitacja czy atom, jak i kategorii odnoszących się do oceny tych teorii, takich jak prosta lub precyzja dowodu. Sens tych i podobnych pojęć okazuje się relatywny wobec obowiązujących paradygmatów i konwencji interpretacyjnych przyjętych przez określoną wspólnotę badania. Uświadomienie sobie historyczności języka nauki stawia realistę wobec trudności znanej jako problem pesymistycznej metaindukcji (Kotowski, 2018, s. 153). Skoro historia nauki dostarcza nam wielu przekładów na to, jak uznane teorie naukowe - wraz z postulowanymi przez nie bytami, takimi jak eter, cieplik czy flogiston - zostają odrzucone, to jaką możemy mieć gwarancję, że to samo nie stanie się z naszymi obecnymi teoriami lub teoriami, które stworzymy w przyszłości? W świetle powyższych rozważań klasyczny realizm wydaje się niemożliwy do utrzymania. Realista nie jest bowiem w stanie spojrzeć z zewnątrz na praktyki naukowe i powiedzieć, że oto nauka poznała - lub choćby zbliżyła się do poznania - prawdę na temat tego, jaki świat naprawdę jest (Fine, 1984, s. 99). Realistyczne intuicje zdają się mieć w gruncie rzeczy religijny charakter - można w nie wierzyć, ale trudno znaleźć przekonujące argumenty, które by za nimi przemawiały.

Zwolennicy realizmu konfrontowani z tymi lub podobnymi zarzutami ripostują niekiedy, że jedynie realizm jest w stanie przekonująco wyjaśnić sukces nauki. Zgodnie z tym argumentem, jeżeli nauka nie byłaby adekwatnym odzwierciedleniem rzeczywistości, jej sukces musiałby zostać uznany za cud. Teza ta jest jednak nieprzekonująca $w$ świetle alternatywnych interpretacji praktyk naukowych, których dostarczają instrumentalizm i konstruktywizm. Można powołać się w tym względzie na pragmatyczne lub instrumentalistyczne kryterium za- 
proponowane kiedyś przez Mary Hesse (Hesse, 1980, s. xi). Zgodnie z tym poglądem cechą wyróżniającą naukę nie jest coraz wierniejsze odwzorowywanie obiektywnej rzeczywistości, lecz postępująca zdolność do przewidywania i kontroli. Zauważmy, że instrumentalizm w wersji proponowanej przez Hesse daje się stosunkowo łatwo uzgodnić z interpretacjami nauki, które przedstawia konstruktywistyczna socjologia wiedzy. Możemy bowiem przyjąć, że instrumentalny sukces określonej teorii naukowej nie wyklucza tego, abyśmy dopatrywali się wpływu rozmaitych czynników społecznych (ideologii, norm kulturowych, stosunków władzy, uwarunkowań klasowych) na sposób, w jaki dana teoria została sformułowana. Instrumentalista, który jest również konstruktywistą, dysponuje zatem całym arsenałem możliwych socjologicznych wyjaśnień sukcesu poszczególnych teorii naukowych ${ }^{2}$. Co więcej, konstruktywizm, jak trafnie wskazuje Arthur Fine, podważa jedną z kluczowych realistycznych intuicji, a mianowicie przekonanie, że nauka dysponuje uprzywilejowanym dostępem do natury prawdy lub istoty rzeczywistości (Fine, 1996). Z socjologicznego punktu widzenia praktyki naukowe nie różnią się niczym od innych praktyk społecznych być może poza faktem, że dyrektywy oparte na ustaleniach naukowych cechuje szczególnie wysoki współczynnik technologicznej skuteczności. Innymi słowy, pytanie o to, jaki musi być świat, żeby nauka była możliwa, ma z konstruktywistycznej perspektywy podobny sens jak pytanie o to, jakie są ontologiczne presupozycje dowolnej innej praktyki społecznej, na przykład uprawiania polityki, wychowywania dzieci lub pożarnictwa.

Stanowisko Mary Hesse ma interesujące konsekwencje dla sposobu rozumienia różnicy między naukami przyrodniczymi a naukami społecznymi. Otóż zdaniem Hesse nauki społeczne nie spełniają sformułowanego przez nią kryterium pragmatycznego, gdyż zjawisko narastającej zdolności do przewidywania i kontroli w ich obrębie zwyczajnie nie występuje (Hesse, 1980, s. 187-205). Innymi słowy, instrumentalizm w tym wydaniu nie ma zastosowania do nauk społecznych. Niedostrzeżenie tej różnicy przesądziło o porażce propozycji Miltona Friedmana, który w znanym artykule The Methodology of Positive Economics przekonywał, że teorie ekonomiczne nie powinny być oceniane przez pryzmat realistyczności założeń, lecz według sukcesu prognostycznego przewidywań z nich wypływających (Friedman, 2008). Co interesujące, podobny błąd popełniają niektórzy współcześni rzecznicy konstruktywizmu w filozofii ekonomii, tacy jak Bartosz Scheuer, który usiłuje nadać propozycji Friedmana konstruktywistyczną interpretację (Scheuer, 2016, s. 94-98). Problem w tym, że istniejące teorie ekonomiczne oraz skonstruowane na ich podstawie modele ekonome-

Odnotujmy tutaj, że podobne stanowisko co Mary Hesse zajął też poznański filozof Jerzy Kmita. Autor ten zachowywał jednak pewne elementy realizmu (Kmita, 1985; Szahaj, 1993). 
tryczne zwyczajnie nie objawily znaczącego sukcesu predykcyjnego, co wykazały między innymi badania prowadzone w ramach socjologicznie zorientowanej socjologii nauki (Beckert, 2016, s. 217-268). Co więcej, instrumentalizm w wydaniu Hesse bynajmniej nie wyklucza badania założeń ideologicznych tkwiących za danymi teoriami naukowymi, podczas gdy główną motywacją instrumentalizmu Friedmana było zablokowanie właśnie tej możliwości (Hesse, 1980, s. 2960; Beckert, 2016, s. 262). Jak się wydaje, instrumentalizm w wersji przyjętej przez Friedmana motywowany był w dużej mierze chęcią immunizacji założeń ekonomii neoklasycznej przed krytyką, kwestionującą ich niską wiarygodność lub ideologiczny charakter.

W obliczu instrumentalistycznych i konstruktywistycznych argumentów realiści niekiedy porzucają realistyczną interpretację teorii naukowych, zadawalając się jakąś skromniejszą wersją realizmu (Fine, 1991; Kotowski, 2018). Najczęściej spotykanymi strategiami są próby trywializacji stanowiska realistycznego lub sformułowania różnych wersji realizmu cząstkowego, uznających realność elektronów, hormonów oraz innych bytów nieobserwowalnych, których istnienie jest postulowane przez teorie naukowe lub przyjmowane za pewnik w praktyce laboratoryjnej. Przykładem stanowiska realistycznego w odniesieniu do ontologii mikrocząsteczek może być realizm laboratoryjny zaproponowany przez Iana Hackinga (Hacking, 1982). Filozof ten zakłada, iż możemy przypisać istnienie cząstkom takim jak elektrony dlatego, że potrafimy nimi manipulować w toku przeprowadzanych w laboratorium eksperymentów. Rozstrzygającym argumentem na rzecz istnienia elektronów są według Hackinga sukcesy inżynieryjne projektów, które opierają się na określonych właściwościach elektronów. $\mathrm{Z}$ kolei przykładem strywializowanego realizmu może być przedstawiona przez Arthura Fine'a koncepcja naturalnego nastawienia ontologicznego (natural ontological attitude, w skrócie: NOA), którą on sam uznaje za stanowisko sytuujące się poza opozycją realizm-antyrealizm. Zdaniem Fine’a powinniśmy uznać istnienie bytów postulowanych przez naukę w taki sam sposób, w jaki uznajemy istnienie przedmiotów w naszym bezpośrednim otoczeniu (Fine, 1984, s. 95). Mamy zatem prawo do posługiwania się referencyjną semantyką i stosowania kategorii prawdy w odniesieniu do ustaleń nauki. Jednocześnie Fine uznaje prawdę za pojęcie pierwotne, odmawiając odpowiedzi na pytanie, czy prawdziwość polega na zgodności z rzeczywistością, wewnętrznej spójności, instrumentalnej skuteczności czy czymś jeszcze innym. W ten sposób NOA usiłuje pozostać neutralna w sporze między realizmem a antyrealizmem.

Moim celem nie jest tutaj ocena referowanych stanowisk. Chciałbym jednak odnotować, że przyczyny akceptacji jakiejś wersji realizmu przez badaczy zajmujących się przyrodoznawstwem różnią się istotnie od argumentów, na które powołują się często rzecznicy realizmu w naukach społecznych. Zauważmy, że 
stanowisko strywializowanego realizmu, uznające realność świata danego w doświadczeniu, nie wydaje się szczególnie interesujące z punktu widzenia nauk społecznych. W istocie jednym $\mathrm{z}$ głównych motywów angażowania się w badania prowadzone $\mathrm{w}$ ich obrębie jest właśnie chęć zakwestionowania zdroworozsądkowej wizji świata. Podobnie wygląda sprawa $\mathrm{z}$ argumentacją realistyczną odwołującą się do sukcesów nauki eksperymentalnej. Jednym $\mathrm{z}$ argumentów, które mają przemawiać za realizmem w sprawie istnienia bytów nieobserwowalnych, jest to, że teorie na nich oparte wykazują dużą skuteczność w wyjaśnianiu zależności przyczynowych. Podobną argumentację formułują niekiedy zwolennicy realizmu w naukach społecznych, postulując istnienie głębokich, nieobserwowalnych struktur lub utrzymując, że przypisanie realności określonym kategoriom teoretycznym jest niezbędne, aby wyjaśnić relacje przyczynowe zakładane przez te teorie. Trzeba jednak pamiętać, że nauki społeczne mogą pochwalić się dużo skromniejszymi rezultatami w zakresie odkrywania istniejących w świecie zależności przyczynowych, niż dzieje się to w przypadku przyrodoznawstwa. W konsekwencji wywód odwołujący się do przyczynowej skuteczności lub wymogów ontologicznych stawianych przez określone teorie jest raczej marnym argumentem na rzecz przyjęcia stanowiska realistycznego w naukach społecznych. Co więcej, powody, które przemawiają za istnieniem atomów czy grawitacji, różnią się istotnie od racji uzasadniających uznanie realności takich kategorii, jak patriarchat, klasa panująca czy samoregulujący się rynek. Jak się wydaje, w tym drugim przypadku chodzi nie tylko o wyjaśnienie występowania określonych zjawisk, lecz także - a może przede wszystkim - o promowanie jednej z konkurencyjnych wizji świata społecznego. W naukach społecznych polityka wiąże się z ontologią w sposób dużo bardziej bezpośredni niż w większości dyskusji toczonych w obrębie przyrodoznawstwa.

Podsumujmy dotychczasowe ustalenia. Większość ludzi, w tym ogromna rzesza badaczy społecznych, spontanicznie akceptuje realistyczną intuicję, że nauka mówi nam, jaki świat jest naprawdę, niezależnie od naszego wyobrażenia o nim. Niemniej stanowisko realistyczne nie jest wolne od istotnych trudności. Po pierwsze, jak starałem się pokazać, podstawowa metafizyczna intuicja realizmu o możliwości poznania świata samego w sobie jest trudna do utrzymania w świetle wiedzy o funkcjonowaniu nauki, jakiej dostarczają współczesna filozofia i socjologia. Być może, jak sugeruje Arthur Fine, podejmowane współcześnie próby reanimacji realizmu dają się interpretować jako chęć zaprzeczenia tezie o jego nieodwołalnej śmierci - zaprzeczenie zaś, jak wiemy z psychologii, jest pierwszą fazą żałoby (Fine, 1984, s. 83). Tak czy inaczej, nawet pobieżny przegląd współczesnych dyskusji w obszarze filozofii nauki pokazuje, że istnieją bardzo poważne argumenty przeciwko przyjmowaniu stanowiska realistycznego w metafizycznym wydaniu. Po drugie, jak widzieliśmy na przykładzie instru- 
mentalizmu i niektórych wersji realizmu, rozważań odnoszących się do przyrodoznawstwa nie da się bezpośrednio przenieść na grunt nauk społecznych. Dotyczy to w szczególności tych stanowisk, które w niekwestionowanych osiągnięciach nauki w zakresie wyjaśniania zależności przyczynowych lub formułowania prognoz dopatrują się argumentów na rzecz przyjęcia określonego stanowiska epistemologicznego bądź metafizycznego. W naukach społecznych nie dysponujemy równie niekontrowersyjnymi przykładami eksplanacyjnego lub predykcyjnego sukcesu - w związku z tym argumenty z powodzenia nauki odniesione do nauk społecznych mają niewielką siłę przekonywania.

\section{Realistyczna ontologia czy społeczna konstrukcja rzeczywistości?}

Jak starałem się pokazać, argumenty wywodzące się z filozofii nauk przyrodniczych nie zapewniają wystarczającego wsparcia dla stanowiska realistycznego w naukach społecznych. Realista może wskazać jednak na dodatkowe racje przemawiające za przyjęciem jego propozycji - i to racje, które mogłyby być częściowo uznane przez interpretacjonistę. Jak wspomniałem wcześniej, interpretacjonista jest przekonany, że teorie rozwijane w naukach społecznych nie różnią się co do istoty od znanych $\mathrm{z}$ historii systemów filozofii politycznej. Możemy zatem zastosować do nich te same kategorie analizy, które zwyczajowo stosujemy do opisu stanowisk filozoficznych. Rzecz jasna, $z$ tej perspektywy zasadne wydaje się pytanie o to, jaka wizja świata kryje się za poszczególnymi teoriami społecznymi. W tej części artykułu postaram się zilustrować, jak takie badania ontologiczne mogą wyglądać, odwołując się do prac Tony’ego Lawsona i Uskali Mäkiego w filozofii ekonomii. Lawson zajmuje się ekonomią głównego nurtu ujętą jako całość i jego stanowisko można scharakteryzować jako ultrakrytyczne. Mäki wypowiada się o jednej z koncepcji ekonomicznych - teorii konkurencji doskonałej - i jego podejście można opisać jako umiarkowanie krytyczne. Obaj autorzy pokazują, że namysł nad ontologicznymi założeniami tkwiącymi u podłoża współczesnych koncepcji ekonomicznych istotnie wzbogaca naszą wiedzę. Co więcej, zgadzam się z sugestią Lawsona i Mäkiego, że nasza ocena ogólnej wizji świata stojącej za daną teorią społeczną często determinuje to, czy ją akceptujemy, czy nie. Sądzę jednak, że koncepcje te nie oznaczają jeszcze akceptacji stanowiska realistycznego, co stanie się jasne, gdy przyjrzymy się bliżej temu, jak wygląda dyskusja między rzecznikami konkurencyjnych stanowisk teoretycznych.

Stanowisko Lawsona rekonstruuję na podstawie artykułu The Nature of Heterodox Economics (Lawson, 2006). Brytyjski realista jest przekonany, że różnica między ekonomią głównego nurtu a nurtami heterodoksyjnymi ma charakter 
ontologiczny. Utrzymuje, że ekonomia głównego nurtu opiera się na założeniach ontologicznych, których nie mogą zaakceptować rzecznicy heterodoksji. Założenia te nie są jednak wypowiedziane wprost, lecz przyjęte implicite w metodologii akceptowanej przez ekonomię neoklasyczną i pokrewne orientacje badawcze. Najbardziej charakterystyczną cechą owej metodologii jest według Lawsona matematyczny formalizm. W tym kontekście Lawson zadaje pytanie, jak musiałby wyglądać świat, gdyby miał on funkcjonować tak, jak zakładają to modele ekonomiczne oparte na podejściu matematyczno-dedukcyjnym. Według Lawsona ekonomia głównego nurtu bazuje na następujących tezach ontologicznych. Po pierwsze, postuluje ona istnienie systemów zamkniętych, w których występują stabilne, deterministyczne regularności. Po drugie, ekonomia zakłada atomizm oraz izolacjonizm, a więc taką sytuację, w której tożsamość podmiotu jest niezależna od relacji, w jakie jest on zaangażowany. Czyni tak $\mathrm{z}$ tego powodu, że takie wyizolowane atomy łatwiej jest ująć w postaci zmiennych w dedukcyjnym modelu matematycznym. Takie ujęcie rzeczywistości społecznej jest jednak zdaniem Lawsona błędne, gdyż ignoruje ono takie fenomeny, jak niepewność, relacje międzyludzkie czy wpływ czynników spoza systemu ekonomicznego, takich jak kultura czy stosunki klasowe. Wymienione elementy rzeczywistości są z kolei w centrum uwagi heterodoksyjnych teorii ekonomicznych, takich jak instytucjonalizm, marksizm, postkeynesizm czy ujęcia feministyczne. Najbardziej podstawowa różnica między ekonomią heterodoksyjną a ekonomią głównego nurtu polega więc $\mathrm{w}$ opinii Lawsona na przyjęciu skrajnie odmiennych założeń dotyczących natury świata społecznego.

Argumentację Uskali Mäkiego rekonstruuję na podstawie rozdziału The Way World Works (WWW): Towards an Ontology of Theory Choice, zamieszczonego w pracy The Economic World View (Mäki, 2001b). Fiński filozof utrzymuje, że na akceptację teorii w naukach społecznych wpływają trzy zestawy kryteriów: empiryczne, społeczne i ontologiczne. Pierwsze dotyczą stosowania uznanych metod weryfikacji faktów, drugie zgodności z wartościami istotnymi dla badacza lub szerszej społeczności, trzecie zaś - „podstawowych składników rzeczywistości społecznej, ich przyczynowych właściwości oraz innych rodzajów zależności między nimi, a także występujących wśród nich mechanizmów zmiany" (Mäki, 2001b, s. 370). Ten trzeci zestaw kryteriów ograniczających swobodę teoretyzowania w naukach społecznych Mäki określa mianem sposobu, w jaki działa świat. Jego zdaniem często odrzucamy określone teorie w naukach społecznych, gdyż wydają się nam one niezgodne z naszym poczuciem tego, w jaki sposób świat funkcjonuje. Mäki ilustruje ten pogląd, odwołując się do teorii konkurencji doskonałej oraz jej krytyki ze strony ekonomii kosztów transakcyjnych oraz ekonomii informacji. Fiński ekonomista i filozof wskazuje, że dla rzeczników teorii kosztów transakcyjnych, takich jak Ronald Coase, teoria konkurencji do- 
skonałej jest nieakceptowalna, ponieważ nie uwzględnia kluczowego elementu rzeczywistości społecznej, jakim są instytucje, w tym instytucja rynku. Z kolei według zwolenników ekonomii informacji, takich jak George Richardson, teoria ta pomija zjawisko niepełnej wiedzy, bez którego nie da się wyjaśnić rzeczywistej konkurencji rynkowej. Mäki wyciąga $\mathrm{z}$ tych argumentów ogólny wniosek dotyczący ontologicznych ograniczeń nakładanych na teorie społeczne. Choć każda teoria z konieczności pomija wiele aspektów rzeczywistości i przyjmuje szereg nierealistycznych założeń, to swoboda postępowania w tym względzie ma określone granice. Teoria nie może bowiem ignorować sposobu, w jaki świat naprawdę działa. Innymi słowy, przynajmniej podstawowe założenia, na których opierają się teorie społeczne, muszą mieć realistyczny charakter.

To nie przypadek, że argumentacja realistyczna jest obecnie formułowana przede wszystkim w filozofii ekonomii. Ekonomia stanowi bowiem tę naukę społeczną, która jest najczęściej oskarżana o utratę kontaktu z rzeczywistością. Odnotujmy, że Lawson i Mäki różnią się co do tego, jak bardzo odklejona od rzeczywistości jest ekonomia. O ile Mäki zdaje się sądzić, że nagannie nierealistyczne są jedynie pewne jej założenia, o tyle dla Lawsona cały projekt ekonomii głównego nurtu polega na upartym ignorowaniu najbardziej elementarnych cech rzeczywistości społecznej. Choć obawy, jakie wyrażają Lawson i Mäki, są dobrze uzasadnione, nie sądzę, aby filozoficzny realizm dysponował antidotum na bolączki współczesnej ekonomii. Samo postawienie problemu realistyczności założeń, na co słusznie zwraca uwagę Bartosz Scheuer (Scheuer, 2016, s. 96), zakłada akceptację jakiejś wersji korespondencyjnej teorii prawdy. Nie można wszak mówić o realistyczności założeń bez przyjęcia poglądu, że pewna wyodrębniona część teorii (a mianowicie jej główne założenia) adekwatnie odzwierciedla obiektywny stan rzeczywistości społecznej. Rzecz w tym, że nie dysponujemy żadnym testem, który pozwalałby nam ocenić, czy taka relacja korespondencji lub reprezentacji rzeczywiście występuje. Kontrowersje dotyczące tego, czy założenia, na których opiera się określona teoria, są realistyczne w sensie postulowanym przez rzeczników filozoficznego realizmu, okazują się zatem z natury nierozstrzygalne.

Warto odnotować, że nie musimy przyjmować stanowiska realistycznego, by móc oceniać wiarygodność założeń stojących za teoriami ekonomicznymi. Aby zrozumieć, dlaczego tak jest, powrócimy raz jeszcze do sporu realistów z instrumentalistami w filozofii nauki. W szeregu artykułów Arthur Fine pokazuje, w jaki sposób możemy sformułować stanowisko instrumentalistyczne mniej restrykcyjnie, niż czyni to na przykład Mary Hesse, do której poglądów nawiązywałem w poprzedniej części tekstu (Fine, 2011). Filozof odwołuje się w tym celu do pragmatyzmu Johna Deweya, od którego pochodzi samo pojęcie „instrumentalizm”. Według Fine’a tym, czego instrumentalista oczekuje od teorii, modeli i metod badawczych, jest ogólna wiarygodność w realizowaniu różnych celów badania. 
Możemy więc mówić o „wiarygodności w odniesieniu do negocjowania naszego postępowania i manipulowania napotkanymi obiektami, wiarygodności w odniesieniu do zwieńczonej sukcesem komunikacji, wiarygodności w zakresie rozumienia i wyjaśniania tego, co się dzieje, wiarygodności w tej mierze, w jakiej przyczynia się ona do trafnych przewidywań" (Fine, 2001, s. 110). Jak widzimy, tak rozumiany instrumentalizm nie ogranicza się jedynie do funkcji predykcyjnej teorii, jak to czyni Hesse, nie traktuje teorii wyłącznie jako „biletów do wnioskowania" (inference tickets), jak proponował kiedyś Gilbert Ryle, ani nie sprowadza ich roli tylko do użytecznego podsumowania dużej ilości danych empirycznych, jak sugerowały niektóre wersje empiryzmu (Fine, 2001, s. 110). Teorie są zatem traktowane jako wielofunkcyjne narzędzia badania, które mają służyć rozmaitym celem, jakie sobie stawiamy w naukach przyrodniczych i społecznych. Z perspektywy pragmatycznego instrumentalizmu możemy dać nierealistyczną odpowiedź na pytanie, dlaczego interesujemy się wiarygodnością założeń leżących u podstaw teorii ekonomicznych. Otóż ocena wiarygodności założeń jest po prostu elementem ogólnego procesu oceny wiarygodności danej teorii - elementem, który w sytuacji braku przekonujących sukcesów predykcyjnych może odegrać rolę zasadniczą.

Pomimo tych zastrzeżeń sądzę, że Lawson i Mäki mają rację, kiedy sugerują, iż obraz świata, jaki proponują różne teorie społeczne, ma zasadnicze znaczenie dla ich przyjęcia lub odrzucenia. Dzieje się tak dlatego, że teorie społeczne bynajmniej nie są neutralne wobec wielkich sporów ideologicznych współczesności. To właśnie ideologiczne uwikłanie - a nie realizm założeń lub jego brak - jest zasadniczym podłożem kontrowersji między różnymi stanowiskami funkcjonującymi w obrębie nauk społecznych. Jak dowodzi Alasdair MacIntyre, każda ideologia informuje nas przede wszystkim o tym, jaki charakter ma rzeczywistość społeczna (MacIntyre, 1984, s. 91-92). W obrębie rozbudowanego stanowiska ideologicznego elementy normatywne i opisowe są zatem splecione ze sobą w sposób, który uniemożliwia ich ścisłe oddzielenie. Interesujące teorie społeczne, jak przekonuje z kolei Charles Taylor, charakteryzują się określonym nachyleniem wartościującym (Taylor, 1985, s. 73). Sugerują one, że pewne cele i wartości dają się zrealizować, podczas gdy inne przedstawiane są jako trudne do osiągnięcia lub zgoła niemożliwe. Przyjęcie określonego poglądu na to, jak działa świat - by posłużyć się terminologią Mäkiego - ma więc istotny wpływ na nasze polityczne wybory. W rezultacie nie sposób dyskutować o ontologii, nie poruszając przy tym fundamentalnych kwestii politycznych. Można powiedzieć, że im ciekawsza jest dana teoria społeczna - im więcej zjawisk usiłuje wyjaśnić, im donioślejsze problemy podejmuje, im bardziej kontrowersyjne są jej twierdzenia etc. - tym większą rolę w jej ocenie będą odgrywały względy polityczne. $Z$ tej racji podstawowe rozstrzygnięcia ontologiczne są uzależnione od przesądzeń o charakterze ideologicznym i kulturowym. W tej sytuacji można przyjąć, że kontury rzeczywistości spo- 
łecznej wyłaniają się ze sporów różnych wspólnot interpretacyjnych, jak chciałby Stanley Fish (Fish, 2002), zmagań pomiędzy zwaśnionymi tradycjami ideologicznymi, jak powiedziałby MacIntyre (MacIntyre, 2007), czy walki konkurencyjnych projektów hegemonicznych, jak za Antoniem Gramscim powtarzają Chantal Mouffe i Ernesto Laclau (Laclau, Mouffe, 2007; Wróblewski, 2016). Zbliżoną tezę można wyrazić w terminologii filozoficznej Jerzego Kmity, mówiąc, że o sposobie ontologicznego umeblowania świata przesądza ostatecznie kultura. Taki jest bowiem sens postulowanego przez Kmitę „radykalnego odwrócenia perspektywy Johna Locke'a" (Kmita, 2007). Tym, co wspólne dla wszystkich tych wypowiedzi, jest przeświadczenie, że język i społeczna konstrukcja znaczenia determinują nasze postrzeganie świata. W tym sensie możemy powiedzieć, że interpretacja ma pierwszeństwo nad ontologią.

Uznanie trafności tych konkluzji nie musi jeszcze oznaczać odrzucenia roszczeń do obiektywności czy całkowitego zanegowania różnicy między nauką a polityką. Po pierwsze, musimy myśleć o obiektywności jako o relacji między teoriami, a nie jako o relacji między nimi a światem. Istotne kontrowersje naukowe nigdy nie są rozstrzygane przez konfrontacje teorii z rzeczywistością. Jedyne, co możemy zrobić, to porównać ze sobą wizje świata oferowane przez różne teorie (Blakely, 2016, s. 96-97). W istocie Lawson i Mäki tak właśnie postępują, porównując ortodoksję $\mathrm{z}$ heterodoksją oraz teorię konkurencji doskonałej z nową ekonomią instytucjonalną i ekonomią informacji. Wertykalny model weryfikacji koncepcji naukowych, zakładający sprawdzenie teorii poprzez wykazanie jej zgodności z rzeczywistością, należy więc zastąpić modelem horyzontalnym, w którym o sukcesie teorii decyduje to, czy jest ona w stanie wykazać swoją wyższość $\mathrm{w}$ konfrontacji z konkurencyjnymi podejściami. Po drugie, musimy porzucić nadzieję na znalezienie kryterium demarkacyjnego, pozwalającego raz na zawsze oddzielić naukę od ideologii. Co najwyżej możemy powiedzieć, odwołując się do terminologii Stanleya Fisha, że wspólnoty naukowe narzucają inne standardy argumentowania i prowadzenia sporów niż wspólnoty polityczne. Misją nauk społecznych nie jest wzbicie się ponad konflikt przeciwstawnych tradycji ideologicznych - nie jest to bowiem możliwe - lecz próba podniesienia jakości argumentów, które w tym sporze występują

\section{Realizm i interpretacjonizm wobec praktyki badawczej w naukach społecznych}

Jak starałem się pokazać na przykładzie prac Lawsona i Mäkiego, poprzez zwrócenie uwagi na rolę ontologii realizm istotnie przyczynił się do pogłębienia naszego rozumienia charakteru teorii społecznych i ekonomicznych. W tej części 
wywodu chciałbym się odnieść do realistycznych poglądów dotyczących praktyki badawczej realizowanej w naukach społecznych. Tym razem odwołam się do przykładów z zakresu nauk politycznych. W szczególności zmierzam poddać krytyce dwie tezy, które - każda w odmienny sposób - przyznają ontologii uprzywilejowaną rolę $\mathrm{w}$ procesie badawczym. Pierwszy $\mathrm{z}$ tych poglądów formułuje Colin Hay w przeglądowym artykule na temat ontologii zamieszczonym w Oxford Handbook of Contextual Political Analysis (Hay, 2006) ${ }^{3}$. Autor ten jest przekonany, że wybory ontologiczne w sposób logiczny poprzedzają i determinują wybory epistemologiczne i metodologiczne. Zdaniem brytyjskiego politologa proces badawczy w naukach politycznych można przedstawić w sposób następujący: najpierw badacz lub badaczka przyjmują określone założenia ontologiczne na temat charakteru rzeczywistości społecznej, które determinują kolejne wybory w zakresie epistemologii. Te z kolei przesądzają o wyborze określonej metodologii, przez co Hay zdaje się rozumieć rozstrzygnięcia dotyczące konkretnych technik badawczych. Drugi pogląd, który chciałbym poddać krytyce, został elegancko sformułowany przez Davida Marsha i Paula Furlonga w tytule Skóra, a nie sweter (Marsh, Furlong, 2016). Według autorów epistemologia i - w szczególności - ontologia odgrywają w badaniach społecznych rolę tytułowej skóry. Jedną z konsekwencji tej metafory jest twierdzenie, że badacze i badaczki nie mogą dowolnie zmieniać swoich sympatii ontologicznych, przyjmując odmienne ustalenia na potrzeby różnych zamierzeń badawczych. W moim odczuciu poglądy wyrażane przez Haya, Furlonga i Marsha przedstawiają nadmiernie hierarchiczny, uporządkowany i tendencyjny obraz procesu badawczego. Postaram się zatem wykazać, że praktyka badawcza realizowana w obrębie nauk społecznych jest dużo bogatsza i bardziej różnorodna, niż wynikało z jej realistycznej rekonstrukcji.

Zacznijmy od tego, że obraz postępowania badawczego, jaki wyłania się z artykułu Haya, wydaje się nadmiernie uładzony. Można zgodzić się z poglądem brytyjskiego autora, że każdy badacz społeczny przyjmuje - świadomie lub nie - jakieś przeświadczenia odnośnie do badanej materii. Hans-Georg Gadamer określił niegdyś owe przeświadczenia mianem przed-sądów, słusznie twierdząc, że jakiekolwiek poznanie byłoby bez nich niemożliwe (Gadamer, 2007, s. 373375). Nie ma jednak potrzeby zakładać, że badacze i badaczki przystępują do prowadzenia dociekań w pełnym rynsztunku ontologicznym. W istocie wiele podejść w naukach społecznych stara się umniejszać rolę gotowych konceptualizacji, które badacz wnosi ze sobą do procesu badawczego. Przychodzi tu na myśl popularna w socjologii strategia teorii ugruntowanej czy badania utrzyma-

Pomijam tutaj problem, czy Colina Haya można sklasyfikować jako realistę w sensie filozoficznym. Artykuł na temat ontologii jest pod tym względem niejasny, natomiast w innych publikacjach autor deklaruje niekiedy konstruktywistyczne sympatie. 
ne $\mathrm{w}$ duchu etnometodologii. Co więcej, proces badawczy jest $\mathrm{z}$ natury rzeczy otwarty. Oznacza to, że nie można wykluczyć, iż podstawowe kategorie - w tym również nasze najbardziej elementarne wyobrażenia na temat tego, jak działa świat - zostaną zakwestionowane w toku prowadzonych badań. Sytuacja taka zachodzi często w antropologii, gdzie pojęcia, którymi dysponujemy, okazują się niewystarczające do zrozumienia społeczeństwa diametralnie różnego od naszego (Bernstein, 1983, s. 93-108). Być może najbardziej frapującą cechą badań społecznych jest właśnie to, że w ich toku możemy poddać próbie nasze najbardziej podstawowe przekonania.

Przeświadczenie, że w badaniach społecznych najpierw definiujemy podstawowe kategorie ontologii społecznej, a następnie aplikujemy je do wybranej materii, wydaje się filozoficzną lub metodologiczną fikcją. Z interpretacjonistycznego punktu widzenia proces badawczy daje się przedstawić jako ciągły ruch oscylujący między tym, co znane, a tym, co zdaje się niezrozumiałe, między tym, co ogólne, a tym, co szczegółowe, między naszymi kategoriami analitycznymi a pojęciami stosowanymi przez aktorów życia społecznego. W punkcie wyjścia mamy raczej pytanie lub problem, nie zaś w pełni ukształtowaną ontologię. Jak możemy domniemywać, dokonana przez Haya rekonstrukcja procesu badawczego jest trafna w odniesieniu do konfrontacji dobrze wyartykułowanych tradycji badawczych, z których każda dysponuje wyraźnie określoną ontologią, epistemologią i metodologią. Przykładem takiego polemicznego zderzenia może być spór zwolenników instytucjonalizmu historycznego z rzecznikami instytucjonalizmu racjonalnego wyboru we współczesnych naukach politycznych (Blyth, 2006). Istnieje jednak wiele sytuacji, w których zaproponowany przez Haya obraz badania okazuje się nieadekwatny. Jest tak przede wszystkim w badaniach opartych na metodach jakościowych i etnograficznych, w których kontury świata społecznego wyłaniają się dopiero ze snutych przez badanych opowieści.

Podobne trudności wiążą się z zaproponowaną przez Marsha i Furlonga metaforą skóry, którą dla badaczy społecznych ma być wyznawana przez nich ontologia. Marsh i Furlong mają oczywiście rację, że nie sposób prowadzić badań społecznych bez przyjmowania - explicite lub implicite - wielu przesądzeń o charakterze ontologicznym i epistemologicznym. Autorzy wprowadzenia do Teorii $i$ metod w naukach politycznych mylą się jednak, sugerując, że nie można łączyć w badaniach koncepcji ontologicznie ze sobą sprzecznych. Załóżmy, że interdyscyplinarny projekt badawczy chce podjąć problematykę społecznej i ekonomicznej roli pracy opiekuńczej, odwołując się do podejścia feministycznego i ekonomii postkeynesowskiej, dodatkowo korzystając także z teorii ugruntowanej oraz metod jakościowych, takich jak wywiady pogłębione i obserwacja uczestnicząca. Czy ekonomistka i socjolożka, hipotetyczne autorki takiego badania, zobowiązane są najpierw ustalić, w jakiej relacji ontologicznej znajdują 
się wykorzystywane przez nie teorie i narzędzia badawcze? Nie sposób też wykluczyć sytuacji, w której badacz całkiem świadomie posługuje się sprzecznymi ontologicznie teoriami. Wyobraźmy sobie antropologa, który inspiruje się jednocześnie dziełami Clifforda Geertza i Michela Foucaulta. Jak wiadomo, antropologia interpretacyjna Geertza jest zorientowana humanistycznie, akcentując sposoby, na jakie aktorzy nadają znaczenie praktykom społecznym. Z kolei podejście Foucaulta jest antyhumanistyczne i dąży do rozpuszczenia podmiotu w takich kategoriach jak dyskurs czy władza-wiedza. Czy badacz, łącząc w różnych lub nawet w tej samej pracy inspiracje Geertzem i Foucaultem, z konieczności popełnia w ten sposób grzech ontologicznej nieczystości? Współczesne nauki społeczne i humanistykę można sobie wyobrazić jako ogromny jarmark, na którym sprzedawcy krzykliwie zachwalają konkurencyjne ontologie, teorie i metody badawcze. Nabywcy, oprócz tradycyjnej konfekcji ontologicznej, mają do wyboru również takie cuda, jak aktanty, sieci, pola, maszyny pragnące, systemy-światy, a także egzotyczne byty o trudnych do zapamiętania nazwach, które zostały wypożyczone z teorii chaosu i teorii złożoności. Trzeźwe spojrzenie podpowiada, że $w$ takich okolicznościach popularne ontologie są zakładane i zdejmowane bez ustanku - nie tyle nawet jak sweter $\mathrm{z}$ tytułowej metafory Marsha i Furlonga, ile raczej jak rękawiczki.

Podsumujmy. Pisząc o procesie badawczym w naukach społecznych, realiści przypisują wyróżnioną rolę założeniom o charakterze ontologicznym. Wizji tej interpretacjoniści przeciwstawiają obraz badania odwołujący się Gadamerowskiej metafory koła hermeneutycznego lub pragmatycznej metafory rozwiązywania problemów. Z kolei zalecając pragmatyczne podejście do teorii jako do narzędzi służących celom badania, interpretacjonizm sankcjonuje umiarkowany eklektyzm, który zdaje się charakterystyczną cechą współczesnych nauk społecznych. Interpretacjoniści przychylnie patrzą na podejmowane przez realistów próby zwrócenia uwagi badaczy społecznych na ontologiczne aspekty teorii naukowych. Zapał w odkrywaniu ukrytych - a nieraz całkiem jawnych - założeń ontologicznych nie powinien jednak przesłaniać faktu, że znaczna część praktyki badawczej realizowanej w naukach społecznych ma niewiele wspólnego z celowym rozwijaniem określonego stanowiska ontologicznego. Co więcej, zdaniem interpretacjonistów nie ma dobrych powodów, dla których sytuacja ta powinna ulec zmianie.

\section{Zakończenie}

Jak się wydaje, zainteresowanie badaczy i badaczek społecznych filozofią nauki bierze się po części z trosk i niepokojów, które są nieodłącznie związane z praktyką badawczą nauk społecznych. Nawet pobieżne spojrzenie na współczesne 
nauki społeczne wskazuje, że cechuje je niebywała różnorodność stanowisk teoretycznych, podejmowanych tematów, konwencji terminologicznych i deklarowanych celów badawczych. Przełomy teoretyczne i metodologiczne ogłaszane są z niebywałą regularnością, organizowane są szkoły letnie propagujące stosowanie zaawansowanych technik badawczych, profesjonalne czasopisma przyjmują coraz bardziej wyśrubowane standardy recenzyjne. Jednocześnie całej tej imponującej aktywności towarzyszą poważne wątpliwości - czasem wyrażane wprost, czasem tylko podskórnie odczuwane - dotyczące statusu uzyskiwanych wyników. Obawy te są dodatkowo podsycane przez świadomość, że w żadnej istotnej kwestii nie udało się dotąd uzyskać naukowego konsensusu. Obserwacja Charlesa Lindbloma i Davida Cohena, jakoby niekonkluzywność była najbardziej uderzającą cechą badań prowadzonych w naukach społecznych, pozostaje w mocy prawie 40 lat od jej sformułowania (Lindblom, Cohen, 1979, s. 40-53). W tej sytuacji badacze społeczni zwracają się w stronę filozofii, aby ta wyjawiła im sekrety metody naukowej lub utwierdziła w przekonaniu, że to, czym się zajmują, naprawdę zasługuje na miano nauki.

Zdaje się, że popularność różnych odmian pozytywizmu brała się głównie stąd, iż lansowana przez pozytywistów metodologia oferowała sposób na uśmierzenie tych niepokojów. Przekonanie o tym, że posługujemy się właściwą metodą, przynajmniej częściowo rozwiewało wątpliwości odczuwane przez praktykujących badaczy co do wiarygodności uzyskiwanych rezultatów. Dodatkowe zapewnienie, że jest to zasadniczo ta sama metoda, która przyniosła sukces naukom przyrodniczym, pozytywnie wpływało na samoocenę badaczy społecznych i pozwalało z optymizmem patrzeć w przyszłość. Bez znaczenia było przy tym to, że pozytywistyczne rekomendacje metodologiczne okazywały się niemożliwe do zastosowania, a lansowane przez pozytywistów wyobrażenie nauk społecznych jako wolnych od wartości dyscyplin teoretycznych groteskowo odbiegało od najbardziej elementarnych spostrzeżeń na temat ich codziennego funkcjonowania. Kryzys pozytywizmu sprawia, że coraz większa liczba adeptów i adeptek nauk politycznych poszukuje alternatywnych sposobów rozumienia własnej praktyki badawczej. Zarówno interpretacjonizm, jak i realizm odpowiadają na tę potrzebę, dostarczając całościowych wizji tego, czym są lub mogą być nauki społeczne i polityczne. Jednak tego rodzaju propozycje powinny być traktowane jako inspiracja, nie zaś jako kolejna próba kodyfikacji obowiązujących norm naukowego postępowania. Osobiście sądzę, że filozofia nauki nie ma autorytetu do tego, aby wskazywać właściwą drogę naukom społecznym. Być może najważniejszą lekcją, którą należy wyciągnąć z porażki pozytywizmu, jest przekonanie, że silnie normatywne metodologie wywołują więcej szkody niż pożytku. Przestroga ta dotyczy w równiej mierze zwolenników realizmu, jak i interpretacjonistów. 


\section{Literatura}

Beckert, J. (2016). Imagined Futures: Fictional Expectations and Capitalist Dynamics. Cambridge, MA: Harvard University Press.

Benton, T., Craib, I. (2003). Filozofia nauk społecznych. Od pozytywizmu do postmoderni$z m u$, przeł. L. Rasiński. Wrocław: Wydawnictwo Dolnośląskiej Szkoły Wyższej Edukacji TWP.

Bernstein, R. (1983). Beyond Objectivism and Relativism: Science, Hermeneutics and Praxis. Philadelphia: University of Pennsylvania Press.

Bernstein, R. (2015). Odnowa teorii społecznej i politycznej, przeł. J. Grzymski, M. Kassner, A. Orzechowski. Wrocław: Wydawnictwo Dolnośląskiej Szkoły Wyższej.

Bevir, M., Rhodes, R.A.W. (2016). „Interpretive Political Science: Mapping the Field”. W: M. Bevir, R.A.W. Rhodes (eds.). Routledge Handbook of Interpretive Political Science. London-New York: Routledge.

Bhaskar R., Laclau, E. (1998). „Discourse Theory vs Critical Realism”. Alethia, 1 (2), s. 9-14. Bińczyk, E. (2013). „Problem sceptycyzmu wobec zmiany klimatycznej a postkonstruktywizm”. Przeglad Kulturoznawczy, 1, s. 48-66.

Blakely, J. (2016). Alasdair MacIntyre, Charles Taylor and the Demise of Naturalism: Reunifying Political Theory and Social Science. Notre Dame: Notre Dame University Press.

Blyth, M. (2006). „Instytucje i idee”. W: D. Marsh, G. Stoker (red.). Teorie i metody w naukach politycznych. Kraków: Wydawnictwo Uniwersytetu Jagiellońskiego, s. 295-314.

Cartwright, N. (1989). „Capacities and Abstractions”. W: Ph. Kitcher, W.C. Salmon (eds.). Scientific Explanation. Minneapolis: University of Minnesota Press, s. 349-356.

Cartwright, N. (2009). „If No Capacities, Than No Credible Worlds. But Can Model Reveal Capacities?". Erkenntnis, 70 (1), s. 45-58.

Elster, J. (1989). Nuts and Bolts for the Social Sciences. Cambridge: Cambridge University Press.

Fine, A. (1984). „Natural Ontological Attitude”. W: J. Leplin (ed.). Scientific Realism. Berkeley, CA: University of California Press, s. 83-107.

Fine, A. (1991). „Piecemeal Realism”. Philosophical Studies: An International Journal for Philosophy in the Analytic Tradition, 61 (1/2), s. 79-96.

Fine, A. (1996). „Science Made Up: Constructivist Sociology of Scientific Knowledge”. W: P. Gallison, D. Stump (eds.). The Disunity of Science: Boundaries, Context and Power. Stanford: Stanford University Press, s. 231-254.

Fine, A. (1998). „Scientific Realism and Antirealism”. W: E. Craig (ed.). Routledge Encyclopedia of Philosophy, vol. 8. London-New York: Routledge, s. 580-584.

Fine, A. (2001). „The Scientific Image Twenty Years Later”. Philosophical Studies: An International Journal for Philosophy in the Analytic Tradition, 106 (1-2), s. 107-122.

Fish, S. (2002). Interpretacja, retoryka, polityka. Eseje wybrane, przeł. K. Abriszewski [et al.]. Kraków: Universitas. 
Friedman, M. (2008). „The Methodology of Positive Economics”. W: D.M. Hausman (ed.). The Philosophy of Economics: An Anthology. Cambridge: Cambridge University Press, s. 145-178.

Gadamer, H.-G. (2007). Prawda i metoda. Zarys hermeneutyki filozoficznej, przeł. i wstępem opatrzył B. Baran. Warszawa: Wydawnictwo Naukowe PWN.

Grzymski, J. (2016). Powrót do Europy - polski dyskurs. Wyznaczanie perspektywy krytycznej. Warszawa: Oficyna Wydawnicza Uczelni Łazarskiego.

Hacking, I. (1982). „Experimentation and Scientific Realism”. Philosophical Topics, 13 (1), s. 71-87.

Harding, S.G. (1976). „Introduction”. W: S.G. Harding (ed.). Can Theories Be Refuted? Essays on the Duhem-Quine Thesis. Dordrecht-Boston: D. Riedel Publishing Company, s. ix-xxi.

Hardt, Ł. (2016). „Modele w ekonomii”. W: M. Gorazda, Ł. Kwarciński (red.). Metaekonomia. Zagadnienia z filozofii ekonomii. Kraków: Copernicus Center Press, s. 223-251.

Hay, C. (2006). „Political Ontology”. W: R. Goodin, Ch. Tilly (eds.). The Oxford Handbook of Contextual Political Analysis. Oxford: Oxford University Press, s. 78-96.

Hesse, M. (1980). Revolutions and Reconstructions in the Philosophy of Science. Bloomington-London: Indiana University Press.

Hollis, M. (2003). „Philosophy of Social Science”. W: N. Bunnin, E.P. Tsui-James (eds.). The Blackwell Companion to Philosophy. Second Edition. Malden-Oxford: Blackwell Publishing, s. 375-403.

Kmita, J. (1985). „Epistemologia w oczach kulturoznawcy”. Studia Filozoficzne, 4, s. 17-36.

Kmita, J. (2007). „Radykalne odwrócenie perspektywy Locke’”. W: J. Kmita. Konieczne serio ironisty. O przekształcaniu problemów filozoficznych w kulturoznawcze. Poznań: Wydawnictwo Naukowe Uniwersytetu im. Adama Mickiewicza, s. 7-38.

Kotowski, M. (2018). „Quo vadis, realisme? O obecnym stanie sporu o realizm naukowy”. Filozofia Nauki, 26, s. 151-164.

Krauz-Mozer, B. (2005). Teorie polityki: założenia metodologiczne. Warszawa: Wydawnictwo Naukowe PWN.

Laclau, E., Mouffe, Ch. (2007). Hegemonia i socjalistyczna strategia. Przyczynek do projektu radykalnej polityki demokratycznej, przeł. S. Królak, wstęp S. Sierakowski. Wrocław: Wydawnictwo Naukowe Dolnośląskiej Szkoły Wyższej.

Lawson, T. (2006). „The Nature of Heterodox Economics”. Cambridge Journal of Economics, 30, s. 483-505.

Lindblom, Ch.E., Cohen, D.K. (1979). Usable Knowledge: Social Science and Social Problem Solving. New Haven-London: Yale University Press.

Lukes, S. (1978). „The Underdetermination of Theory by Data”. Proceedings of Aristotelian Society. Supplementary Volumes, 52, s. 92-107.

MacIntyre, A. (1984). Against the Self Images of the Age: Essays on Ideology and Philosophy. Notre Dame: University of Notre Dame Press. 
MacIntyre, A. (2007). Czyja sprawiedliwość? Jaka racjonalność?, przekł. zbiorowy. Warszawa: Wydawnictwa Akademickie i Profesjonalne.

Mäki, U. (2001a). „Economic Ontology: Why? What? How?”. W: The Economic World View: Studies in the Ontology of Economics. Cambridge: Cambridge University Press, s. 3-15.

Mäki, U. (2001b). „The Way World Works (WWW): Towards Ontology of Theory Choice?". W: The Economic World View: Studies in the Ontology of Economics. Cambridge: Cambridge University Press, s. 369-389.

Marsh, D., Furlong, P. (2016). „Skóra, a nie sweter: ontologia i epistemologia w politologii”. W: D. Marsh, G. Stoker (red.). Teorie i metody w naukach politycznych. Kraków: Wydawnictwo Uniwersytetu Jagiellońskiego, s. 17-40.

Outhwaite, W. (1987). New Philosophies of Social Science: Realism, Hermeneutics, and Critical Theory. London: Macmillan Education Ltd.

Scheuer, B. (2016). „Konstruktywizm w ekonomii”. W: M. Gorazda, Ł. Kwarciński (red.). Metaekonomia. Zagadnienia z filozofii ekonomii. Kraków: Copernicus Center Press, s. 69-105.

Szahaj, A. (1993). „Jerzy Kmita: między modernizmem a postmodernizmem”. Acta Universitatis Nicolai Copernici. Filozofia XV, s. 75-84.

Taylor, Ch. (1985). „Neutrality in Political Science”. W: Ch. Taylor. Philosophy of the Social Sciences. Collected Papers vol. 2. Cambridge: Cambridge University Press, s. 58-90.

Wróblewski, M. (2016). Hegemonia i władza. Filozofia polityczna Antonio Gramsciego i jej współczesne kontynuacje. Toruń: Wydawnictwo Naukowe UMK.

Zybertowicz, A. (1995). Przemoc i poznanie: studium z nie-klasycznej socjologii wiedzy. Toruń: Wydawnictwo Naukowe UMK.

\section{Streszczenie}

Artykuł konfrontuje ze sobą stanowisko realistyczne i interpretacjonistyczne w filozofii nauk społecznych. Autor stawia tezę o pierwszeństwie interpretacji przed realistycznie pojmowaną ontologią, którą to tezę należy rozumieć na trzy sposoby. Po pierwsze, o tym, czym jest nauka (w tym nauki przyrodnicze), dowiadujemy się, interpretując praktyki badawcze podejmowane przez kulturowo usytuowane wspólnoty badania, nie zaś stawiając metafizyczne pytania o naturę rzeczywistości. Po drugie, w perspektywie interpretacjonizmu ogólny obraz rzeczywistości społecznej (i politycznej) jest pochodną zwycięstwa jednej ze stron w sporze interpretacyjnym między różnymi tradycjami ideologicznymi. Po trzecie wreszcie, proces badawczy w naukach społecznych nie jest zdeterminowany przyjętymi z góry założeniami o charakterze ontologicznym. Z tego względu zdaniem interpretacjonistów lepiej jest myśleć o badaniach społecznych, posługując się Gadamerowską metaforą koła hermeneutycznego lub pragmatyczną metaforą rozwiazywania problemów.

Słowa kluczowe: pragmatyzm, hermeneutyka, realizm, antyrealizm, konstruktywizm, instrumentalizm 